\title{
Erratum to: Electropolymerization of hydroxyphenylacetic acid isomers and the development of a bioelectrode for the diagnosis of bacterial meningitis
}

\section{Luciano Pereira Rodrigues $^{1} \cdot$ Deusmaque Carneiro Ferreira $^{1} \cdot$ Lucas Franco Ferreira $^{2} \cdot$ Sara Cuadros-Orellana $^{3}$. Guilherme Corrêa de Oliveira $^{3} \cdot$ Ana G. Brito-Madurro ${ }^{4} \cdot$ Ronaldo Junio de Oliveira $^{5}$. Odonírio Abrahão Jr. ${ }^{6}$. João M. Madurro ${ }^{1}$}

Published online: 2 March 2017

(C) Springer Science+Business Media Dordrecht 2017

\section{Erratum to: J Appl Electrochem (2015) 45:1277-1287}

DOI 10.1007/s10800-015-0892-2

In the original publication of the article, the sentence "The stability tests showed the latter to have superior performance compared with the other matrices studied" has been published incorrectly in the conclusion section. The correct one is "The stability tests showed that poly(3-hydroxyphenylacetic acid) has superior performance compared with the other matrices studied".

The online version of the original article can be found under doi:10.1007/s10800-015-0892-2.

Odonírio Abrahão Jr.

odonirio@biomedicina.uftm.edu.br

1 Laboratório de Filmes Poliméricos e Nanotecnologia, Instituto de Química, Universidade Federal de Uberlândia, Uberlândia, MG, Brazil

2 Laboratório de Eletroquímica e Nanotecnologia, Instituto de Ciência e Tecnologia, Universidade Federal do Vale do Jequitinhonha e Mucuri, Diamantina, MG, Brazil

3 Centro de Excelência em Bioinformática da Fiocruz-Minas, Belo Horizonte, MG, Brazil

4 Instituto de Genética e Bioquímica, Universidade Federal de Uberlândia, Uberlândia, MG, Brazil

5 Departamento de Física, Instituto de Ciências Exatas, Naturais e Educação, Universidade Federal do Triangulo Mineiro, Uberaba, MG, Brazil

6 Instituto de Ciências Biológicas e Naturais, Universidade Federal do Triangulo Mineiro, Uberaba, MG, Brazil 